地すべり 第 29 巻 第 3 号

Journal of Japan Landslide Society 29-3(1992)

\title{
造林木におけるアテ材形成と地すべり変動履歴 \\ Using Dendrochronological Analysis \\ In A Study On History of Landslide Movement
}

\begin{tabular}{|c|c|}
\hline Shunichi KIKUCHI & Tohru ARAYa \\
\hline 青 水 収 ${ }^{*}$ & 中 村 太 士* \\
\hline
\end{tabular}

\begin{abstract}
In general, landslide mass can be divided into small blocks depending upon their activities. The objective of this study is to clarify the historical movement of these blocks using dendrochronological analysis. Firstly, we investigated microtopography and inclination of trees (Abies sachalinensis) planted on gentle slope of the landslide. Secondly, we examined compression woods of tree rings formed in the inclined stems. In terms of compression wood, date of initiation, change in forming direction, and increase in areal extent are important factors to analyze historical movement of landslide.

The landslide investigated is formed by two blocks which indicate different directions and histories of mass movement, although tree ring analysis clarified extensive movements from 1972 to 1973 and from 1986 to 1987 in both blocks. Ring samples in which compression woods are formed in different directions were found at the central area of each block, whereas samples showing extensive compression wood were found near the crack within each block. These results suggest frequent and complex movements in a small scale within a block. キーワード: アテ材解析, 変動履歴, 土塊傾動様式
\end{abstract}

\section{1.はじめに}

斜面の土塊の動きである地すべり変動を力学的に解析 した研究例は過去に多い。こうした研究は個々の地すべ り地に注目しており，すべり面を設定し，土塊の力学的 安定を検討している。たとえば，丸山・近藤（1986）は 土塊移動量の測定，すべり面土層の土質試験により地す べり運動特性を考察している ${ }^{10)}$ 。八木ら（1986）は地す べり粘土の土質力学的検討により, 地すべりの変形挙動

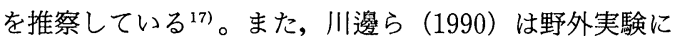
より, 地すべり発生の前段階としての地盤の剪断変形過 程を日単位で解析検討している8

一方，ある広がりをもった地域を対象とし，地形・地 質・雨量データ等の統計解析によって, 地すべり分布特 性を考察した研究例も多い。たとえば，井東ら（1987） は伊豆半島中伊豆地域を対象とし, 調査データ（地形・ 地質・植生・降雨等）を統計解析し，崩壊予測について 検討している゙)。また, 多田ら (1992) は岩手県南西部の 地形的要因と地質的要因について検討を加え, 地すべり
発生場の分布特性について考察している ${ }^{14)} 。$

以上のような解析手法により短時間オーダーの地すべ り運動は徐々に解明されつつあるが, 土地利用を考慮し

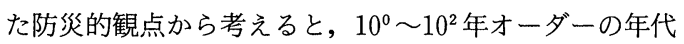
学的解析が必要となる。地すべり斜面は緩傾斜を呈する ため, 土地利用の際には安定域と見誤られ, 農業・リゾー トはもとより居住用地の適地として開発される危険性を 含んでいる。また，林業面では地すべり地が造林適地と 判断され，新規に植栽されることも少なくない。このよ うな背景から地すべり変動の時間的推移を年単位で推察 する試みが過去においてもなされてきた。東ら（1971） は，地すべり変動地に生育している樹木群を対象に，そ の年齢構成と空間的広がりから過去 100 年程度の地表変 動を小面積単位で探る方法を確立しだ)。上中ら (1979) は地質学的調査解析に針葉樹のアテ材（傾倒木の年輪内 に形成される異常材）解析を加えることにより, 地すべ り土塊のブロック状移動履歷について検討している7)。 また下川・地頭溒（1984）は，屋久島においてスギ同齢 林の年齢分布を調査し，山崩れの周期年を推定してい る ${ }^{13)}$ 。

これら樹木年代学的解析手法を用いた既往の研究例で 
は, 樹木群を時間指標として地すべり変動履歴を推察し ているが, さらに踏み込んで, 樹木群の成立する場であ る地すべり土塊の運動について論じた研究例はきわめて 少ない。そこで筆者らは, 地すべり地内に植栽されたト ドマツ造林木を生物計としてとらえ, その傾倒状況とア テ材, さらに微地形解析から, 地すべり変動履歴を明ら かにするとともに, 地すべり土塊の変動プロセスについ て考察を加えることとした。

\section{2. 調査地概要}

白老町は北海道南西部, 札幌市の南方約 $60 \mathrm{~km}$ の距離 にあり, 北は支笏湖, 南は太平洋に面する。対象地すべ り地はこの白老町の森野地区にあり, 白老川(標高 $945 \mathrm{~m}$ の白老岳に源を発し同町を南東に流下, 流路長 $23.5 \mathrm{~km}$, 流域面積 $102.3 \mathrm{~km}^{2}$ ) の河口より約 $11 \mathrm{~km}$ 上流の右岸斜 面に位置している（図-1）。白老川の中・下流では河川 沿いに幅 700〜800 m の河岸段丘が発達し, 河幅は広い が，地すべり地付近ではこの押し出しによって河幅が狭 まっている。

地すべり地の規模は長さ $750 \mathrm{~m}$, 最大幅 $450 \mathrm{~m}$, 面積約 20 ha で, 滑落崖に囲まれた緩斜面 (平均傾斜: 約 $7^{\circ}$ ) は 1944 ・1959 年植栽のトドマツ (Abies sachalinensis) 造 林地（北海道営林局白老事業区 83 林班）となっている。

地層は最下位に第三紀層が分布し，一部は粘土化し， その上面がすべり面と考えられている。そして更に上部 を壮渓珠層および支笏火山噴出物が被覆している。主滑 落崖周辺の裸地部では火山角礫岩や軽石・火山扊・溶結 凝灰岩が露出しており, その崩積土（崖錐堆積物）が各 地層を広く被覆している ${ }^{1), 12) 。 ~}$

この白老町森野地区は北海道において最も降水量の多 い地区のひとつで, 1980 年から 1989 年までの 10 年間で は年平均降水量は $2,294 \mathrm{~mm}$ に達する ${ }^{11)}$ 。また日降水 量 $100 \mathrm{~mm}$ 以上の大雨が年に数回発生するが，そのおも な発生原因が北海道南方を通過する台風や温帯低気圧に よるため, 夏から秋にかけて豪雨が集中する傾向がある といわれている

\section{3. 微地形分布と樹木傾倒}

\section{1 微地形}

一般に地すべり地には特有の微地形がみられ，この微 地形の形状や形成時期から, 地すべり変動様式を推察す ることができる。

調査対象地すべり地の外縁には滑落崖（比高 $20 \sim 30$ m) が馬蹄形に連なり, その直下には大規模な山地が存在 する(図-2)。この滑落崖は 1948 年撮影の航空写真でも 確認されたことから, 主滑落崖を形成した大規模変動の 発生は少なくともそれ以前と考えられる。またその後は
地すべり変動にともなって，白老川に接する舌端部で土 砂崩落が続いている。

主滑落崖と舌端部との間の緩傾斜地表面には大小の亀 裂が確認されたが，それらの植生被覆状況により亀裂発 生の新旧を相対的に判別した。すなわち, 裸地状態のも のは新しく, ササ・草本に被覆されたものはやや古く, さらに木本に被覆されたものはより古いと想定された。

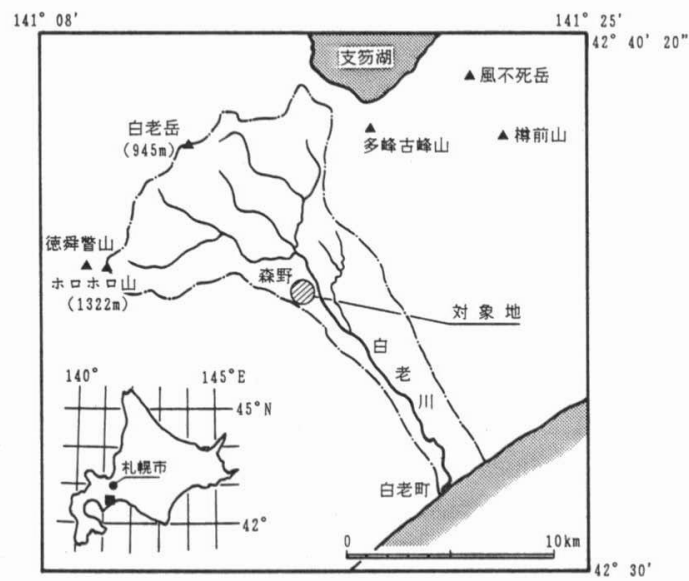

図-1 調查地位置図

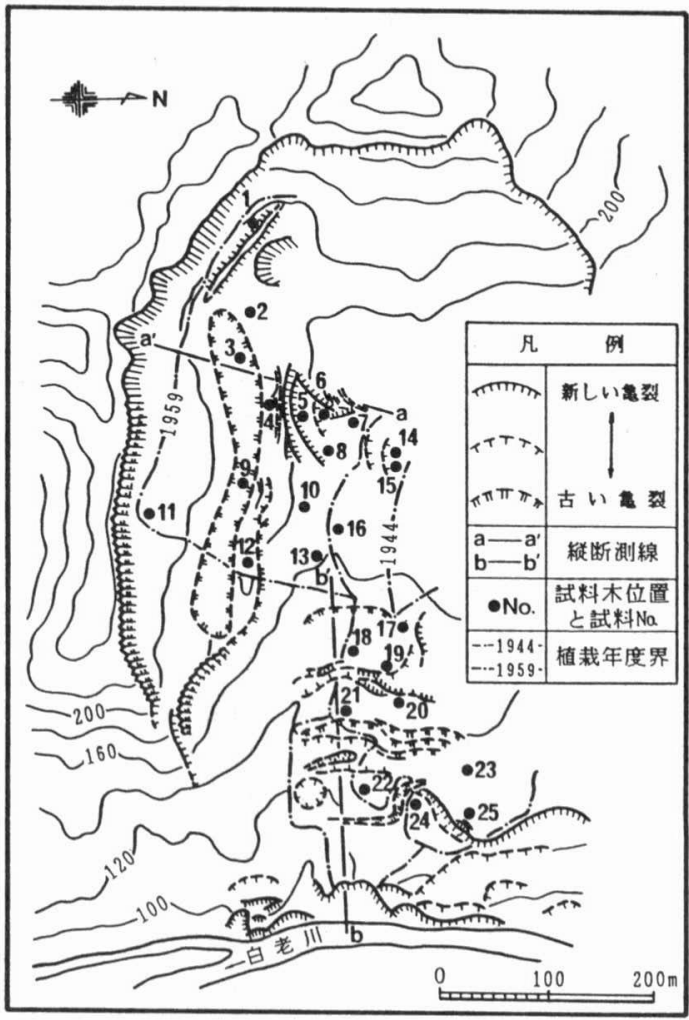

図-2 微地形分布と試料木採取位置 
全体を概観すると標高 $160 \mathrm{~m}$ 付近を境に亀裂の走向 が異なり，標高 $160 \mathrm{~m}$ 以上の区域は東西方向，標高 160 $\mathrm{m}$ 以下白老川渓岸までの区域は南北方向となっている ことから,地すべり土塊は傾動方向の異なる二つのブ ロック (前者: A ブロック, 後者: B ブロック) に大きく 分割された。すなわち，A ブロックは主に北方へ，B ブ ロックは主に東方へ各々傾動していると推測された。

A ブロックの主滑落崖直下に大規模な山地がみられ るが，これは主滑落崖の形成時に土塊が大きく北方へ傾 動した結果と推測される。さらにその北方には, 主滑落 崖に平行な二次滑落崖や新鮮な龟裂が集中分布している 区域がみられる。

一方, B ブロックでは標高 120〜130 m 付近に, ササ類 に被覆され形成時期が古いと考えられる大亀裂 (幅約 30 $\mathrm{m}$, 比高 10〜 $15 \mathrm{~m}$ ) がみられ，この亀裂を境に地すべり 土塊が二分されている。

\section{2 樹木傾倒}

$\mathrm{A} ・ \mathrm{~B}$ ブロックの縦断形状（測線 $\mathrm{a}-\mathrm{a}^{\prime}$ と $\mathrm{b}-\mathrm{b}^{\prime}$ ） と樹 木傾倒状況を図一 3 に示した。

A ブロックでは，新鮮な微地形がとくに集中する二次 滑落崖の北側において, 樹木群がほほ同一方向に傾倒し ていた。3ヶ所で各 10 本, 計 30 本の試料木の傾倒角度を 計測した結果，二次滑落崖の背後 (図中 1])では谷側 (北 方) に $13 \sim 39^{\circ}$ (平均 $20^{\circ}$ ), 二次滑落崖直下 (2) でも谷 側に 17 52 (平均 $30^{\circ}$ ), それより下方 (3) では逆に山 側（南方）へ $20 \sim 39^{\circ}$ (平均 $28^{\circ}$ ) で傾倒していた。すな わち, 新鮮な微地形の周辺では土塊傾動方向（滑落崖や 亀裂に直交する方向）に沿って，樹木群が同一方向に強 く傾倒していた。
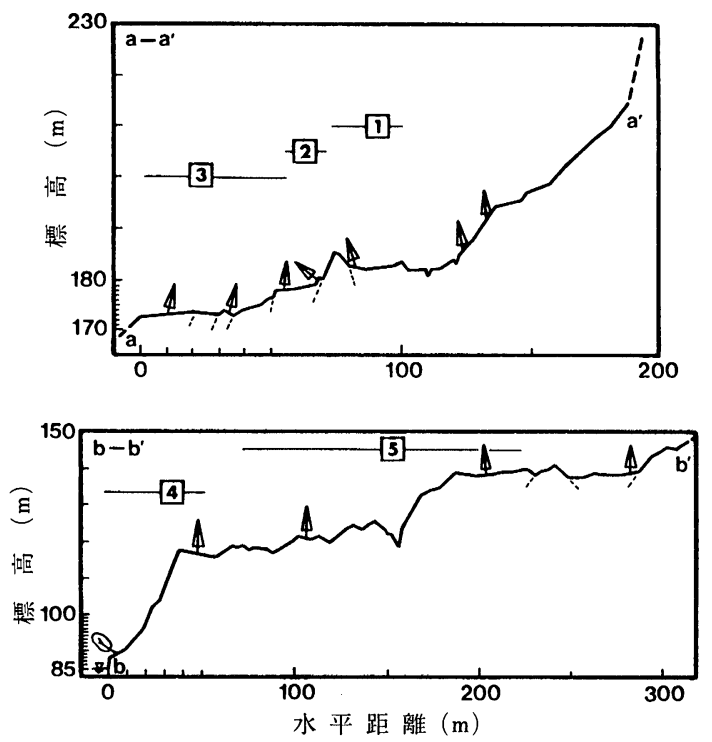

図-3 縦断図
次に B ブロックでは, 波状の不整地形や山地がみられ るが, A ブロックにくらべ, 全体的（末端部の崩壊地を 除く）に形成時期の古い微地形が顕著であった。樹木傾 倒状況は, 末端部 (4) では谷側（東方）に 9〜 36 (平 均 $22^{\circ}$ ）で傾倒していたが，それ以外 (5) では 2〜 $8^{\circ}$ と 角度は小さく，その傾倒方向もばらついていた。

以上のように微地形分布と樹木（群）の傾倒状態から， この地すべり土塊は傾動方向と変動状況の異なる $\mathrm{A}$ と B の 2 ブロックに区分される。つまり主に北方へ傾動し 最近も活発な活動状態にある A ブロックと, 主に東方へ 傾動しているが近年は活動性が衰退し休止状態にある B ブロックの 2 ブロックの存在が推測された。

\section{4. 地すべり変動とアテ材形成}

地すべり地上に生育する樹木は，地表変動にともなっ て極端な場合には倒伏・枯死するが，傾倒した場合には 本来の直立位に立ち直る過程で樹幹を変異させ, その横 断面にはアテ材と呼ばれる異常材を形成することが多く の地すべり地で観察され, 実験的にも実証されてい

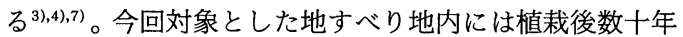
を経過したトドマツ造林木が生育していることから，そ のアテ材の形成状況を解析することによって, 地すべり 変動の履歷および地盤の運動様式についての推察を試み た。

1989 年 $1,3,7$ 月に採取した計 25 本のトドマツ試料木 を解析対象とした。前図一 2 に試料木の採取位置と植栽 年度界を示した。試料木採取に当たっては, 同様の傾倒 状態を示す樹木群から代表的な 1 本を抽出することとし たため, 1944 年植栽域で 12 本, 1959 年植栽域で 13 本の 採取となった。前記のブロック区分に従うと試料 No. 1〜16 は A ブロック, No. 17〜25 は B ブロックに分布 している。試料木の樹高は $10 \sim 14 \mathrm{~m}$, 採取時の傾倒角度 は2 12 (1本のみ $60^{\circ}$ ) の範囲であり, 伐採高は $0.3 \sim 0.4 \mathrm{~m}$ とした。年輪の解析対象期間は, 植栽直後の 幼跲段階に受けると思われる地すべり変動以外の外力 (雪圧, 人為等) の影響を除くため, 植栽後数年を経た 1965 年以後の 24 年間とした。なお, 対象地は緩斜面で雪 崩の発生しにくい地形状況であること, あるいは対象期 間内に風倒被害はでていないことから, 雪圧や風力はア テ材形成の外力としては除外できる。

図-4にアテ材形成の典型例を模式的に示したが，各 試料木のアテ形成状況には次のような特街がみとめられ た。

(1) アテ形成開始（以下，(1) とする)

アテが形成され始めた年を指し, 図ー4では 1979 年 と 1985 年がそれに当たる。また年表の網かけ部分はア テ形成継続期間を示し，図中では 1985～1988 年と 
1979〜1988 年の 2 期間を示した。

(2) アテ形成方向変化 (以下, (2) とする)

アテの形成方向が以前とは異なる方向に相対的に大 きく変化したもので, 図中左の No. 11 では 1986 年に 当り, 前形成期 (1970 1983 年) とは時計回りで約 $100^{\circ}$ 形成方向が変化している。

(3) アテ形成強度増大（以下, (3) とする)

アテの形成継続期間内で, その強度が前年と比較し て明らかに増大したものを選出した。図中右の No. 5 では 1982 年に比べ, 1983 年に形成されたアテ材面積 が著しく拡大している。

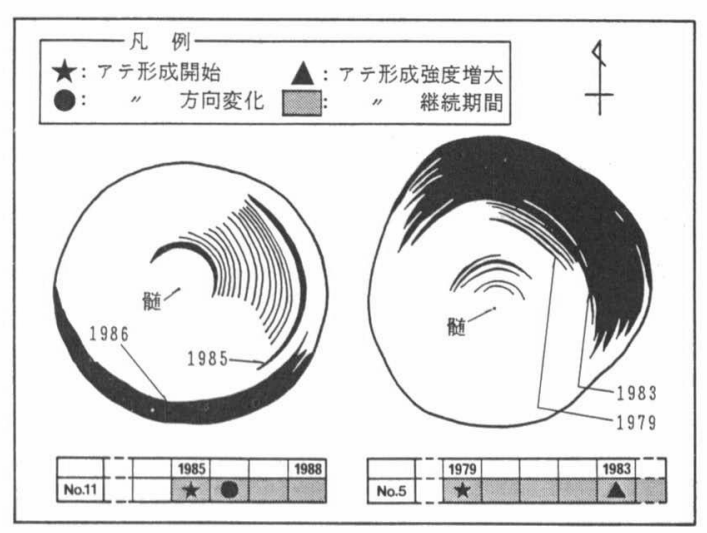

図-4 アテ形成状況
以上の 3 点は, 樹木傾倒痕跡であるアテ材の形成状況 のなかでも, とくに傾倒の新規発生あるいは傾倒状況の 変化発生を表しており, 地すべり変動発生を示す重要な 要素 (以下, 変動要素とする) であると考えられた。そ こでこの三種類の変動要素に着目し, 年輪解析を進めて いくこととした。

\section{5. 変動要素の時間的推移}

図 -5 に全試料木 25 本のアテ形成状況の一覧を示し た。なお試料 No. 1〜 13 は 1959 年植栽木, No. 14〜25 は 1944 年植栽木である。試料木 25 本中 No. 19 を除く 24 本にアテの形成がみられたことは, 対象地のほほ全域に 地すべり変動の影響が現れていることと, No. 19 が不動 点であることを示している。またそれぞれの変動要素(前 章の (1) (2) (3) ) が, 一試料木中に複数回（最高 6 回, 平 均 2.8 回) 現れており, これは同一地点での変動発生の 繰り返し (反復性), および樹幹の直立位復帰にともなう アテ形成開始・終了の繰り返しを示している。

図-6に各試料木の試料採取時の樹幹傾倒度と, その 傾倒に影響したと想定される最も近年の地すべり変動発 生年との関係を示した。両者の関係は図のように, 変動 発生後の経過年数が長いものは傾倒角度が小さい傾向が 認められた。これは 1975 年以降の活動規模が大きかった ためとも考えられるが, 近年のアテ形成のみられない期 間を含むもの（図中○印）の傾倒度が小さいことから，

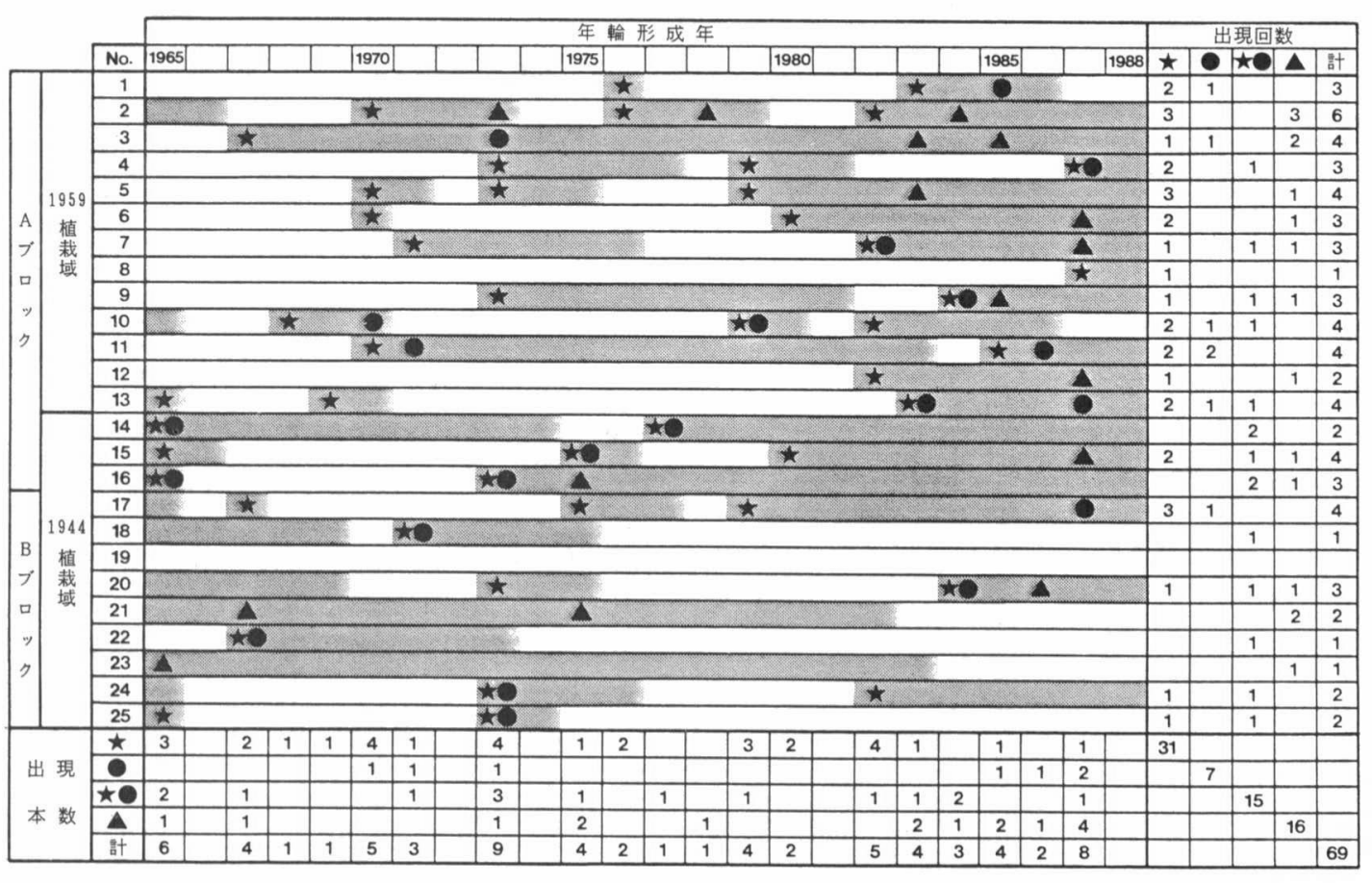

図－5 アテ解析結果一覧 
アテ形成開始後新たな地盤変動を経験しない傾倒樹幹は, 徐々に直立位に復帰していくことを示すものと考えられ る。また, 図一7にアテ形成継続期間の頻度分布を示した が, 2 年間のものが $16.7 \%$ で最も多く, 5 年以内のもので 60\%を超える割合となっている。すなわち一旦傾倒した 樹幹の多くは 5 年以内に直立位に戻り, アテ形成が終了 することがみられる。

図-8に三種類の変動要素をまとめた頻度分布を示し た。この頻度とは各年代において, 変動要素の出現した 試料木本数が総試料木本数に占める割合である。これよ り 1973 年が $36 \%$ で最も頻度高く, 以下 1987,1965 , 1970, 1982 年の頻度が高いのが認められる。

次に各変動要素毎にその頻度の時間的推移を示した (図-9)。まずアテ形成開始（11) については，アテの
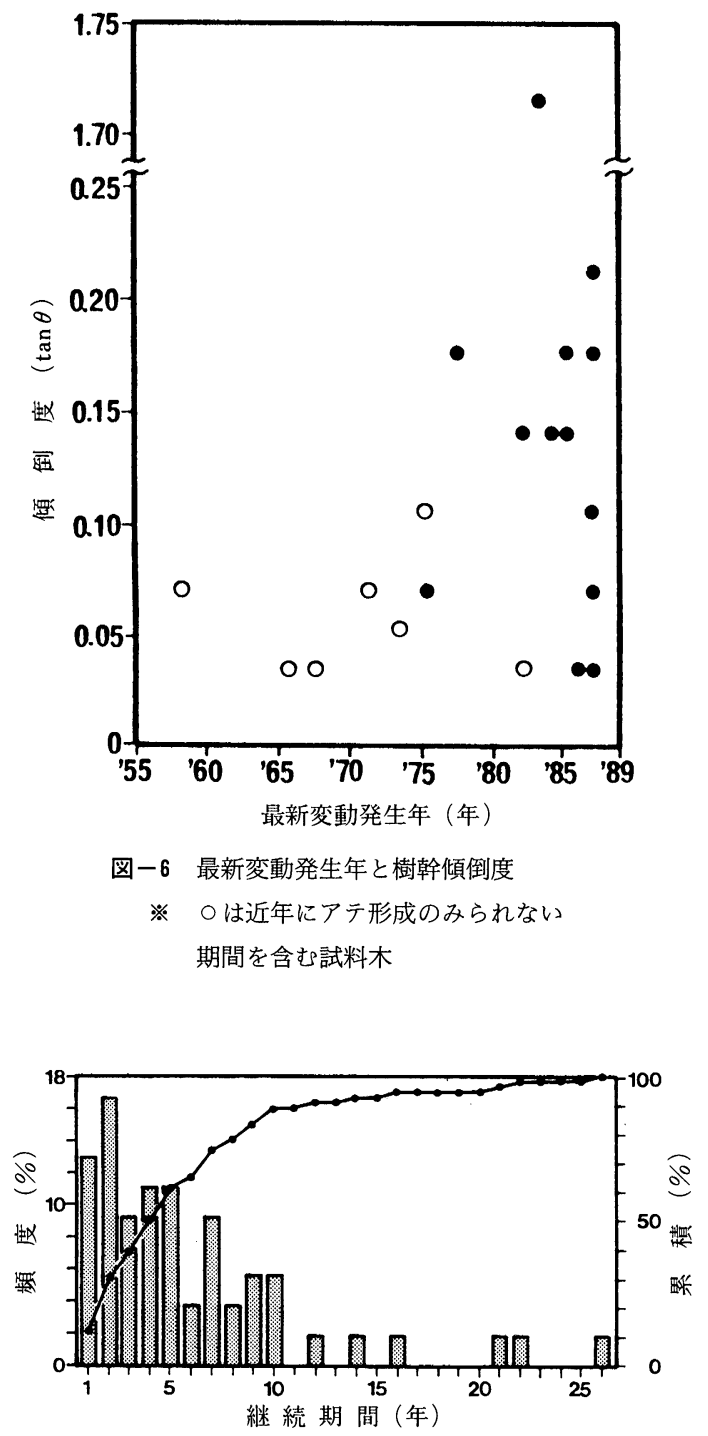

図ー7 アテ形成継続期間
みられた 24 本中 22 本で対象期間中にアテ形成を開始し ていた（No. 21，23 では各々 1962 年と 1958 年よりアテ 形成が継続しているため, 対象期間中にはこの要素が出 現しない)。特に頻度が高いのは 1973 年の $28 \%$ で, 次い で 1965 年と 1982 年の $20 \%$ となている。また対象期間 中アテ形成を複数回開始する試料木が全体の半数以上を 占め, 1969 年から 2 回目のものが, そして 1979 年以降は 3 回目のものが出現している。

次にアテ形成方向変化（2）に関しては，24 本中 17 本に方向変化がみられるが, その様式は次の 2 種類に区 分され,

・その前年にアテ形成がみられなく, 形成開始と同時 に方向が前回とは変化していたもの

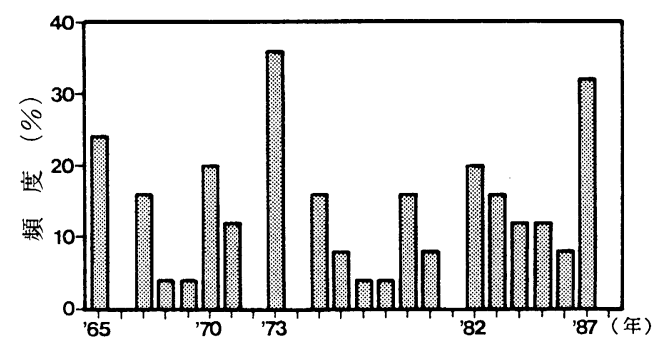

図-8 変動要素の出現年別頻度分布
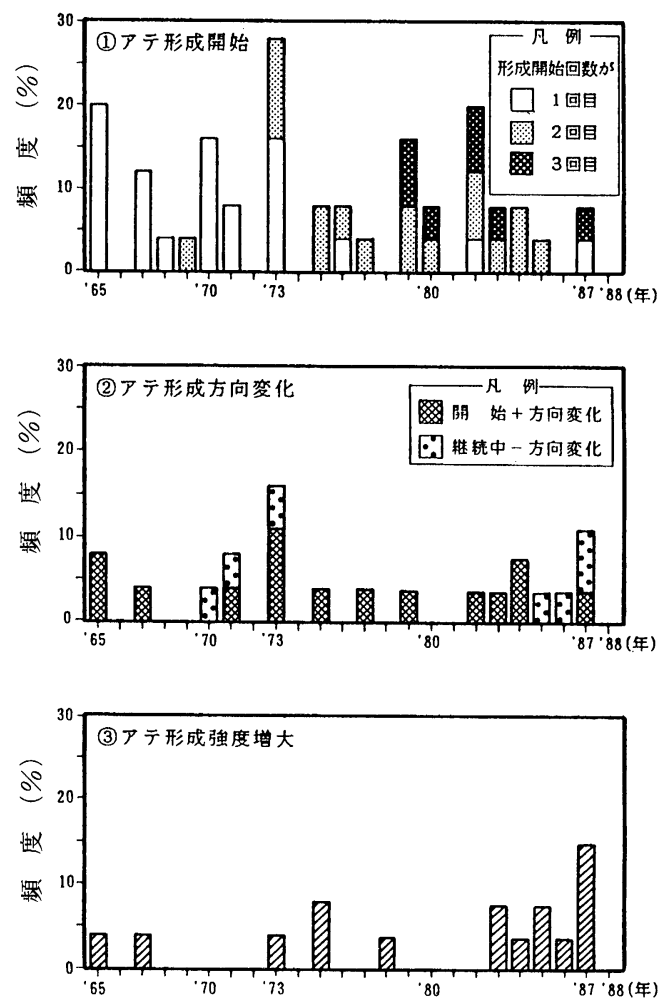

図ー9 各変動要素毎の頻度の時間的推移 
・アテ形成継続中に方向の変化したもの

であり，前者が後者の 2 倍の頻度を示している。両者を 総合した頻度は, (1) と同じ 1973 年に $16 \%$ で最も高いが, 2 番目に高いのは 1987 年である。また全般に頻度は $10 \%$ 以下となっている。

アテ形成強度増大（（3）とはアテ形成継続期間中に, 以前と同一方向に樹木傾倒度が増加したことを示してい る。24 本中 12 本に急激な強度増大がみられ, 特にその頻 度が高いのは (2) と同様に 1987 年の $16 \% て ゙, 1983$ 年より 毎年出現している。その一方で，1968～1972 年の 5 年間 および 1979〜1982 年の 4 年間は出現率 $0 \%$ となってい る。

以上より, 変動要素の頻度の時間的推移をみると, ア テ形成状況には毎年のように変化がみられ, とりわけ 1965，1970，1973，1982，1987 年に変動要素が高頻度に 出現している。当年形成のアテが, 前年の生長休止期か ら当年生長期の間に発生した地すべり変動に対応すると 考えると，地すべり変動はその規模を変化させながらほ ほ毎年発生し, 特に 1964 年生長休止期〜1965 年生長期, 同様に 1969～1970 年, 1972 1973 年, 1981〜1982 年, 1986〜1987 年には広範囲に変動が発生したと考えられ る。なお,通常北海道におけるトドマツの生長期間は 5 月 から 9 月の期間である2),9)。

また，変動要素出現率が $0 \%$ の年は $1966,1972 ， 1974$, 1981，1988 年の 5ヶ年であるが，とりわけ 1966，1974， 1988 年は, 特に広範囲な地すべり変動発生年の翌年に当 たっている。このことは, 大規模な地すべり変動が発生 すると土塊に蓄積されていた歪みが解放されるため，土 塊が一時的な安定を獲得した結果であると推測される。

森野における降雨記録を検討した結果, 1972 年 9 月 16 日には観測史上（1963 年〜）最高となる日雨量 $525 \mathrm{~mm}$ の豪雨が発生している5)。図ー10に 1964〜1988 年間で日 雨量 $100 \mathrm{~mm}$ 以上を記録した降雨 60 例について，地す べり変動規模別に総雨量と最大時間雨量の関係を示した。 図中で大規模変動とは, 広範囲に地すべり変動の生じた

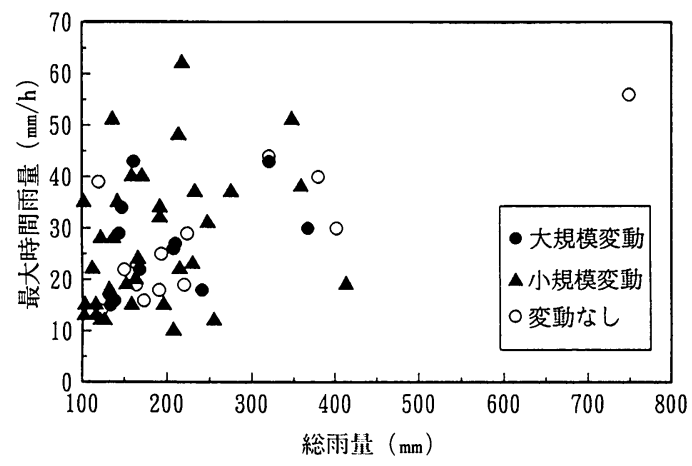

图ー10＼cjkstart降雨状況と地すべり変動規模の関係
前記 5 期間にあたる降雨であり，その他の地すべり変動 発生に対応する降雨は小規模変動とした。先述の通り対 象地ではきわめて降雨が多いが，各降雨は図中にばらつ いて分布しており，地すべり変動の発生状況と総降雨量, あるいは時間降雨強度との関係は明瞭にはみられない。 なお，1986 年生長休止期〜1987 年生長期にあたる 1986 年 10 月・1987 年 5 月には, 主滑落崖付近の斜面において 亀裂発生が確認されており ${ }^{12)}$, 当時の地すべり変動発生 を裏付けている。

\section{6 . 変動要素の空間分布}

前章では地すべり地全域をひとつの単位として変動発 生状況の時間的推移を検討したが, 次に前述のブロック 区分に基づき, 変動要素出現の空間的分布から各ブロッ クの地すべり変動特性を検討する。

三つの変動要素はいずれも地すべり変動発生を表して いることから，これら要素の出現回数を合計し，その分 布状況を図ー11に示した。変動回数はNo.19 の不動点 を除き $1 \sim 6$ 回で, 解析対象期間内 (24 年間) に 3 回以上 の変動発生がみられた地点は約 $60 \%$ に達する。A ブロッ クでは変動回数 3〜 回，B ブロックでは 1〜2 回が主体 で，A ブロックの方が相対的に活動性が高い。さらに前 図－5 から，B ブロック (No. 17〜25) では近年の変動発 生が少ないのに対し，Aブロック（No.1〜16) では近年

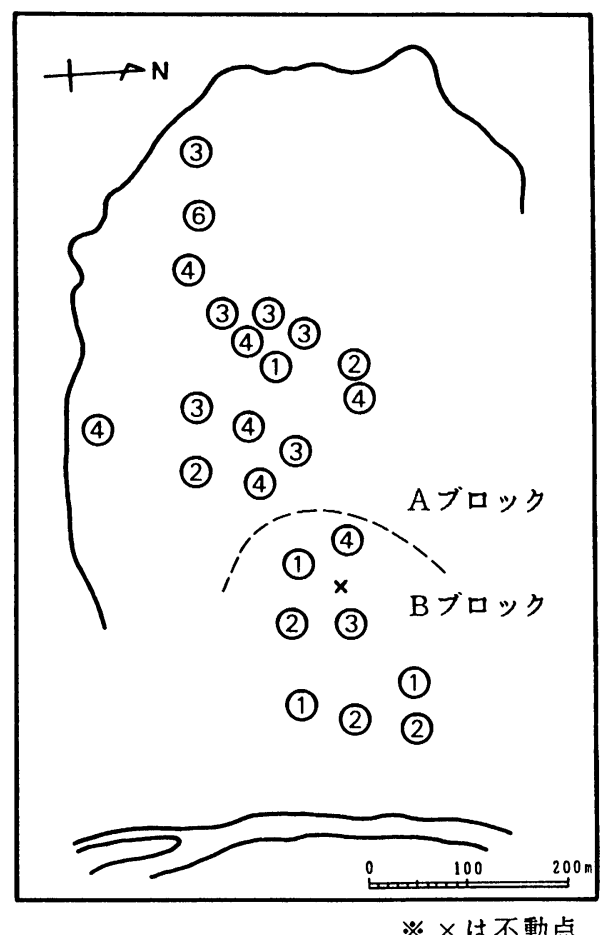

図-11 変動要素出現回数の分布 
における変動発生が多いことがわかる。すなわち, A ブ ロックは過去 24 年間において活動性が高く,近年も活発 に変動が発生しているが, B ブロックでは近年はやや活 動性が衰退しており休止状態にあるものといえる。

つぎに変動要素のうち, 地盤変動方向の変化を示すア テ形成方向変化 ( (2) ) と, 変動強度増大を示すアテ形成 強度増大 ( (3) ) について, それらの空間分布を図一12に 示した。

まずアテ形成方向変化については, 24 地点中 17 地点 (70\%)に方向変化がみられた。そこで，年輪内でアテ分 布の中心を定め, 方向変化角（変化前後における中心の 移動角) を求めたところ, $36^{\circ} \sim 172^{\circ}$ となった。この方向

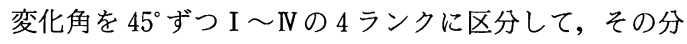
布状況を図示した。但し，実際にアテ形成方向が時計回 り，あるいはその反対のどちらに回転したのかは判別で きないため, 変化角度が $180^{\circ}$ 以下となるように計測し た。なお，方向変化が 2 回生じた地点では上下 2 段に変 化度ランクを示した（上段: 1 回目, 下段: 2 回目)。

方向変化を 2 回経験したものは 5 地点 $(20 \%)$ で, A ブ ロックにのみ存在し, 特に B ブロックとの境界付近に 3 地点が集中している。また方向変化が 1 回のみのものは 12 地点 $(50 \%)$ で，また方向変化の生じなかったものは 7 地点 $(30 \%)$ である。方向変化度が強い III・IVランクの 地点は各ブロックの中央部付近（図中一点鎖線で囲んだ
区域）に集中しており，この区域では各土塊ブロックの 頭部と末端部に挟まれたかたちで土塊内部の変形が進行 していると考えられる。

次に, アテ形成強度増大については, 肉眼的にアテ形 成強度がきわめて増大した年輪について, 増大年とその 前年のアテ材面積を測定し, 増大率を求めた。その結果, 増大率は $190 \%$ ～ $1240 \%$ の範囲となり，これを大・中・小 の 3 ランクに区分した。な打図中で $\boldsymbol{\Delta}$ 印が数個密着して いるのは, 同地点で複数回強度の増大が生じたことを示 している。2 4 地点中 12 地点 (50\%) でアテ形成強度の増 大がみられ, また強度増大率が大・中の地点は, 方向変 化角の大きいIII・IVランクの地点とは異なっていた。す なわち同ブロック内においても，アテ形成強度を増大さ せるような地表面の歪みの現れる地点と，アテ形成方向 を変化させる地表面の歪みが生じる場があることを示し ている。

\section{7. 地すべり変動履歴}

\section{1 変動履歴}

これまでの解析より，この白老森野地すべり地の変動 履歴は次のように推測された。

まず，この地すべり地は 1948 年以前に形成され，その 後も地すべり変動は継続し，大規模な主滑落崖で囲まれ た地すべり土塊内全域に変動が及んでいるようである。
(2) 方向変化

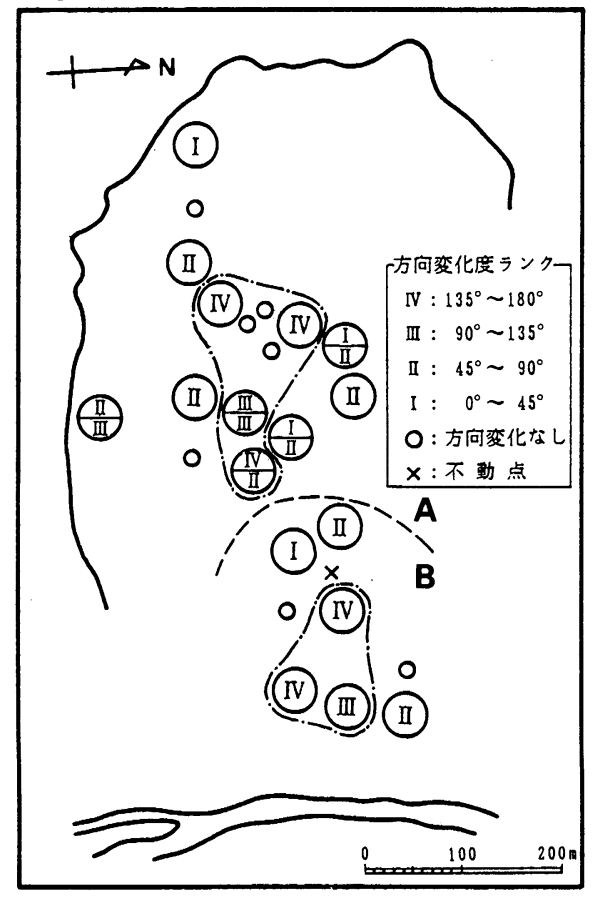

(3) 强度增大

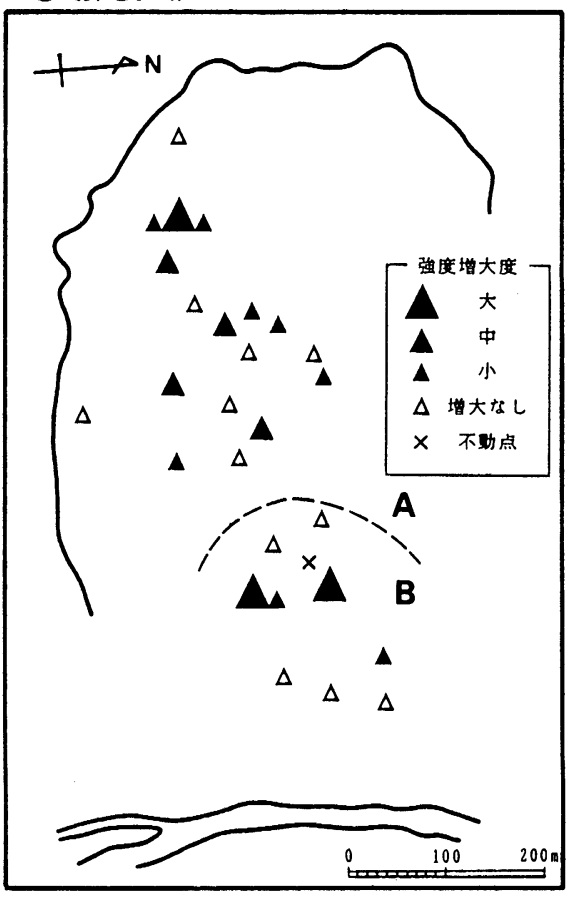

図-12 変動要素の空間分布 
しかし広範囲で同時に, 同規模の, そして同様の変動が 生じることは稀で, きわめて複雑な変動過程を示してい る。

微地形分布と樹木群傾倒状況から, 頭部に近く北方に 傾動する A ブロックと, 舌端部に近く東方に傾動する B ブロックに二分された。そしてこれらのブロックは各々 変動履歴が異なり, A ブロックは近年まで活動性が高 く, 一方の B ブロックは近年は活動性が以前より衰退し 休止状態にあると推測された。

アテ形成状況の解析から, 変動の同時性が広範囲にみ られるのは, 1964 年生長休止期〜1965 年生長期と, 同様 に 1969～1970 年, 1972 1973 年, 1981 1982 年, 1986〜1987 年の 5 時期である。さらに, 特に広範囲に変 動が影響した 1965 年, 1973 年, 1987 年の翌年は活動休 止期となっている。このことから, 小規模の地すべり変 動はほほ毎年発生するが, 豪雨等の誘因のなかった年に は土塊は傾動せずに歪みが蓄積し, 次に誘因が生じると 大規模変動が発生し，またその次年はひずみ蓄積年とな るといった変動の反復過程の存在が想定される。

\section{2 土塊傾動様式}

前述のようなアテ形成状況の変化は, 地すべり変動に ともなう土塊傾動形態の変化に対応して, 樹幹の傾倒状 況が変化した結果であると考えられ，図ー13にそのモデ ルを示した。

まず斜面に直立していた樹木は，土塊の傾動によって ある方向へ傾倒し, アテの形成が開始される。その後, 傾倒樹幹が直立位に戻らぬうちに再度土塊が以前と同方 向に傾動し，樹幹の傾倒度が以前より增大した場合には， アテ形成強度が増大する。また, 以前とは異なる方向に 土塊が傾動したことにより樹幹の傾倒方向が変化したと
きには,アテ形成方向も変化する。つまり先述の (1) は土 塊傾動発生, (2) は土塊傾動方向の変化, (3) は土塊の傾動 量の増大を示すと推測される。とくに (2) と (3) の出現地 点の分布が異なることから, 根張り空間単位 (半径 $2 \sim 3$ $\mathrm{m}$, 深さ 2 3 m の小ブロック ${ }^{16)}$ ) での地盤の傾動様式に は次の 2 種類が考えられる。

1) 多方向型

アテ形成方向変化 ( (2) ) が強度に出現する地点の土 塊は, 2 回目以降の変動時には前回とは異なる方向に 傾動する。つまり地盤が様々な方向へ傾動するタイプ であり,ブロックの頭部や末端部から離れた中央部分 に分布している。これは一変動単位である土塊ブロッ クの中央部分ほど微地形レベルの圧縮や引っ張りなど 多様な変形を受けるためであると考えられる。

2 ) 単一方向型

アテ形成強度増大 ( (3) ) が強く現れる地点の土塊は 新たな変動時にも前回と同方向に傾動し, その地盤傾 動量を増大させる。つまり地盤が単一方向へその傾き を増大させながら傾動するタイプであり, 明瞭なク ラックの周辺に分布している。推測される傾動方向が クラックの走向に直交することから，そのクラック形 成時あるいは変化時に傾動したものと考えられた。

以上のような根張り空間単位での土塊変動様式を踏ま えた上で再び前出図ー5 を検討してみると，同一期に広 い面積で地すべり変動が生じ，なかでも同一方向の傾動 が多かった時期（例えば 1987 年）には，樹木根張り空間 より深い層, すなわち深さ 2 3 m 以深での土塊傾動が 生じたため, その上部に載る小ブロックに類似性を持っ た動きが生じたと考えられる。一方，例えば 1973 年では 同様に広範囲で変動が生じているが, とりわけ方向変化

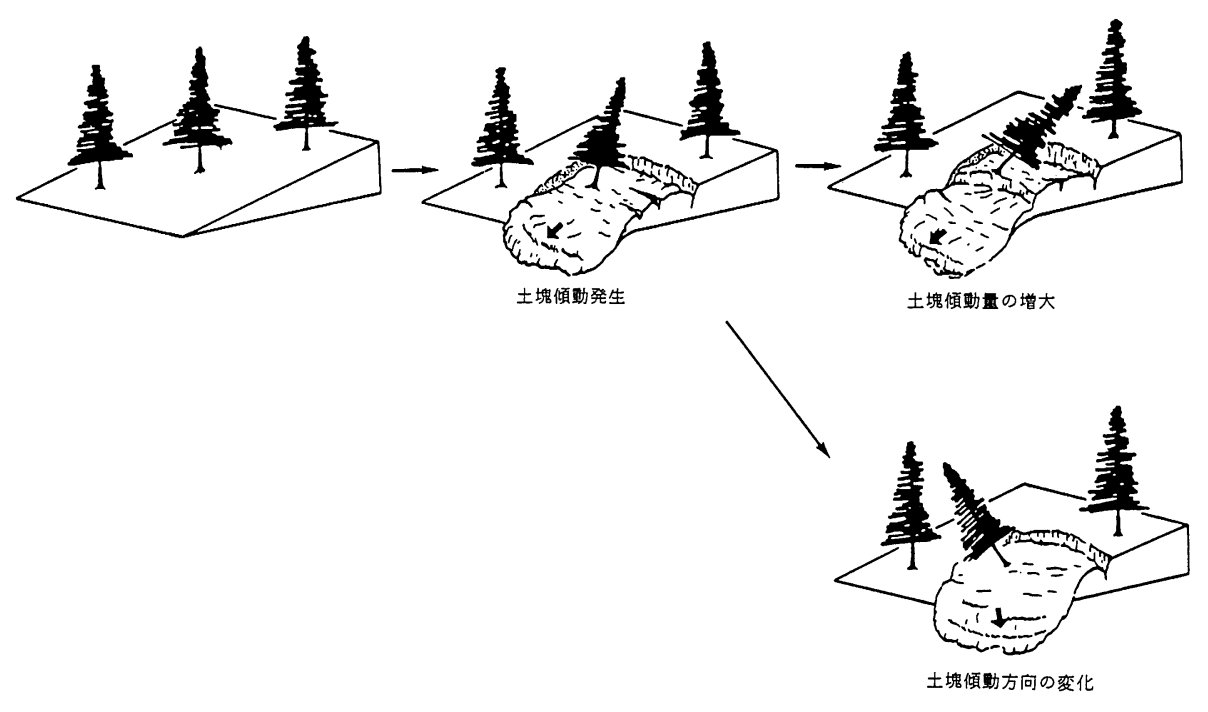

図-13 土塊傾動と樹幹傾倒 
が多い B ブロックでは浅い層（深さ 2 $3 \mathrm{~m}$ ) でのいわゆ る表層破砕のような変動が生じたため, 小ブロックの傾 動様式にはバラツキがみられたものと推測される。

\section{8.おわりに}

地すべり地に植栽されたトドマツ造林木を生物計と見 立て, その樹幹断面に形成されたアテ材の形成状況変化 に注目し, 地すべり変動にともなう地盤傾動様式の推測 を試みた。いわば生物学的手法により無機物の物理的運 動を推察したが, アテ形成と年輪幅変化との対応実態や 地すべりの活動規模など不明な点が多く，未だ推測の域 を脱し得ていない。今後は継続した物理的測定による土 塊傾動情報と生物計情報との関連についての検討を要す ると考える。

最後に, 現地での試料採取に御援助いただいた北海道 営林局治山課, 白老営林署治山課, 国土防災技術株式会 社の関係各位に深く謝意を表する。

\section{参考文献}

1) 土居繁雄: 5 万分の 1 地質図幅「白老」および同説明書, 北海道地下資源調査所, p.37, (1953)

2 ) 藤原好子, 坂上幸雄: トドマツ, アカエゾマツ苗木の生 長, 日本林学会北海道支部講演集, 29, pp.144 146, (1980)

3 ) 深沢和三: トドマツ傾斜苗木の直立化と材形成過程, 北 海道大学農学部演習林研究報告, Vol.30, No. 1, pp. 103 123, (1973)

4 ) 東 三郎, 藤原滉一郎, 新谷 融, 村井延雄: 樹木年代学 からみた地すべり地の推移, 北海道大学農学部演習林研 究報告, Vol. 28, No. 2, pp. 339 420. (1971)
5 ) (社北海道土木協会: 北海道の大雨資料, 第 8 編 (1989)

6 ) 井東澄雄, 石川重雄, 西木敏夫: 斜面表層崩壊予知に関す る推計学的研究一伊豆半島, 中伊豆地域における崩壊予 知分析一,地すべり, 89, Vol. 24, No. 1, pp. 10〜19(1987)

7 ）上中博之, 岡 正範, 佐藤 進, 小貫義男: 岩手県二戸郡 安代町赤川地すべり地の樹木年代学的研究, 地すべり, Vol. 16, No. 1, pp. 21 28 (1979)

8 ）川邊 洋, 芝野博文, 西尾邦彦, 山口伊佐夫: 野外実験に よる地すべり発展過程における地盤の変形特性, 地すべ り, 101, Vol. 27, No. 1, pp. 1〜10（1990）

9 ) 小林昌三: トドマツ産地別苗木の上長 -肥大生長の周期 性, 日本林学会北海道支部講演集, $30, \mathrm{pp}$. 167〜169（1981）

10）丸山清輝, 近藤政司: 滝坂地すべりの運動特性, 地すべ り, 87, Vol. 23, No. 3, pp. 7〜14 (1986)

11）日本気像協会北海道本部: 北海道の気象（1980～1989）

12）応用地質株式会社: 南白老バライト鉱山地すべり対策検 討業務（その 2) 報告書, p. 68（1988）

13）下川悦郎, 地頭薗隆: 屋久島原生自然環境保全地域にお ける土壌の居留時間と屋久スギ, 屋久島原生自然環境保 全地域調查報告書, 環境庁自然保護局, p p . 83 100 (1984)

14）多田元彦, 大河原正文, 千田成人: 岩手県南西部川尻・焼 石岳地域の地すべり地形について, 地すべり, 108, Vol. 28 , No. 4 , pp. $15 \sim 22$ (1992)

15）武田栄一, 菊地勝弘: 北海道の局地的大雨 (I) - 年間降 雨量に対する大雨の寄与について一, 北海道大学地球物 理学研究報告, 37, pp. 19〜29（1978）

16）竹下敬司, 中尾博美, 綿引 靖, 丸谷知已, 森田紘一, 池本 済, ムハマド・ヌルディン, 長澤 喬: 林木根系の 実態とそれに基づく崩壊防止機能の検討, 九州大学農学 部演習林研究報告, No. 66, pp. 83〜129（1992）

17) 八木則男, 榎 明潔, 矢田部龍一, 永江正憲: 犬寄地すべ りの挙動に対する土質力学的検討, 地すべり, 85, Vol. 23 , No. 1 , pp. $8 \sim 15$ (1986)

(原稿受理日 平成 4 年 6 月 1 日)

\section{日本学術会議だより No. 26}

日本学術会議広報委員会より平成 4 年 9 月の日本学術会議だよりNo.26が送られてきました。項目は次の通りですが 詳細をお知りになりたい方は地すべり学会事務局にお申し出下さればコピーをお送りします。

\section{1. 平成 5 年度の共同主催国際会議の閣議了解}

平成 5 年度には 6 国際会議について共同主催するが, 政府としても所要の措置（会場, 警備, 入国手続き上の 配慮, 予算措置等）を講ずる旨の閣議了解を行った。 地すべり学会関連の会議はない。

現在本年末締切りの平成 7 年度共同開催会議の募集を 広報している。（詳細は日本学術会議月報）

\section{2.日本学術会議主催公開講演会}

I 20 世紀の意味と 21 世紀への展望 平成 4 年 10 月 5 日(月)於日本学術会議
II 医学からみた日本の将来 平成 4 年 11 月 28 日(圤於金沢市文化ホール

\section{3. 物理学研究連絡委員会報告}

I 物理学研究の動向と将来への課題

II 理論物理学の研究体制の充実について

\section{4. 材料工学研究連絡委員会報告}

繊維工学研究・教育に関する諸問題 一産学協力による繊維工学研究と教育の振興— 
造林木におけるアテ材形成と地すべり変動歴史

「地すべり」Vol. 29, No. 3 (通巻第 111 号) pp. 1 9, 1992 年（平成 4 年）12月

菊地 俊一, 新谷融, 清水 収, 中村 太士

地すべり地内に植栽されたトドマツ造林木の傾倒とアテ材形成状況を検討し，地すべり変動歴史について推察

した。また地すべり土塊の変動プロセスについて検討した結果, 土塊傾動様式は様々な方向に傾動する多方向型

と, 単一方向へ傾動を繰り返す単一方向型の 2 タイプに分けられた。

各種の回転半径をもつ円弧の結合による複雑な地下すべり面形状の推定

「地すべり」Vol. 29, No. 3 (通巻第 111 号) pp. 10 17, 1992 年（平成 4 年）12月

吉澤 孝和, 夈野 勝, 西澤 茂高

各種の測量で得られた地表諸点の変位ベクトルを解析して, 複雑な地下すべり面の形状を種々の円弧を結合し て推定する手法を考究する。長野県奈良尾地すべり地に対する適用例を示し, 推定したすべり面の信頼度をを, 現 地の諸現象との適合性および安全率によって評価する。

豪雪地帯における地すべり自動観測システムの開発

「地すべり」Vol. 29, No. 3 (通巻第 111 号) pp. 18〜26, 1992 年（平成 4 年） 12 月

松浦 純生, 落合 博貴, 竹内 美次, 梁瀬 秀雄

雪と地すべりの因果関係を解明することを目的として，ハンドヘルドコンピュータを用いた観測システムを開 発し, 1987 年から観測を行ってきた。この自動観測システムで生じた問題点を踏まえ, 旧システムを進化発展さ せた自動観測システムを新たに開発し，1991 年 8 月から運用を開始した。その後 1 年近くにわたり, 新システム による観測を行ってきたのでシステムの概要，問題点などについて報告する。

地すべり地の斜面傾動に伴う土地電位の挙動

「地すべり」Vol. 29, No. 3 (通巻第 111 号) pp. 27〜34, 1992 年（平成 4 年） 12 月 伊藤 芳朗, 南雲 政博

新潟県平丸の地すべり観測システムにおいて，51 日間に及ぶ斜面の傾斜変化に伴って，土地電位（3 成分）に 特徵ある変動がみられた。2 回に及ぶ電位の特異な変動と水位変動から, 斜面内部の带水層の収縮, 崩壊が, 斜面 傾動の原因であり, 電位変動, 地下水変動をもたらす原因であることが判明した(斜面傾動電位効果)。また, 1990 年新潟南部地震の前兆的な電位変化 (地震電位効果) が観測された。土地電位の連続観測は, 地すべり活動の解 明，考察に有力な情報を提供することを示した。

受圧版のたわみ・応力解析

「地すべり」Vol. 29, No. 3 (通巻第 111 号) pp. 35〜 40, 1992 年（平成 4 年） 12 月 柏原公二郎

弾性理論に基づいた受圧版（格子状）の応力解析によると，梁には直接地盤を押さえる「有効区間」と，地盤

より浮き上がる「自由区間」があって，それらは特性值 $(\beta)$ とアンカー間隔（2L）によって決まる。

Chang の式と例題について比較した結果, 支点での差は比較的小さいものの, スパン中央部に至っては大差が 生じた。それは杭と受圧版では条件が異なるためである。 